\title{
Effect of seeding, Belcocel and nitrogen fertilizer rates on yield and yield components of wheat under North Sinai conditions
}

\author{
M. A. El-Hawary ${ }^{1, *}$, G. H. Abd El-Hay ${ }^{1}$, M. A. Attia ${ }^{2}$ and M. A. I. Zaire ${ }^{2}$ \\ 1 Agronomy Department, Faculty of Agriculture, Al-Azhar University, Cairo, Egypt \\ 2 Plant Production Department, Desert Research Center (DRC), Cairo, Egypt
}

*Correspondence: Elhawary@azhar.edu.eg (M. El-Hawary)

\begin{abstract}
Two field experiments were conducted at the experimental farm Agriculture Research Station, Desert Research Center, at El-Qantara, North Sinai Governorate, Egypt, during 2015/2016 and 2016/2017 seasons, to investigate the effect of three seeding rates $\left(400,500\right.$ and 600 seeds $/ \mathrm{m}^{2}$ ), three belcocel rates (sprayed plants by tap water, belcocel at a rate of $750 \mathrm{~cm}^{3} /$ fed once added and $375 \mathrm{~cm}^{3}$ twice added) and four nitrogen fertilizer rates $(0,70,90$ and $110 \mathrm{~kg} \mathrm{~N} / \mathrm{fed})$ on yield and yield components of wheat. A split- split plot design with three replications was used. Sowing wheat plants at seeding rate of 600 seeds $/ \mathrm{m}^{2}$ gave the highest number of spikes $/ \mathrm{m}^{2}$, spike length, number of grains/spike, grain yield/feddan and straw yield/feddan as compared with other seeding rates in both seasons, as well as harvest index in first season. Spraying wheat plant with belcocel at the rate of $375 \mathrm{~cm}^{3} /$ feddan twice at 21 and 40 days from sowing date gave the highest values of number of spikes $/ \mathrm{m}^{2}$, spike length, number of grains/spike, 1000 grains weight, grain yield/feddan, straw yield/feddan and harvest index in both seasons .Increasing nitrogen fertilizer up to $90 \mathrm{~kg} \mathrm{~N} / \mathrm{feddan}$ significantly increased number of spike/ $\mathrm{m}^{2}$, spike length, number of grains/spike,1000 grain weight, grain yield/feddan, strew yield/feddan, harvest index, in both seasons. Sowing wheat plants with seeding rate of 600 seeds $/ \mathrm{m}^{2}$, sprayed by belcocel twice at the rate of $375 \mathrm{~cm}^{3} /$ feddan and fertilized by nitrogen at the rate of $90 \mathrm{~kg} \mathrm{~N} / \mathrm{feddan}$ gave the highest number of spikes $/ \mathrm{m}^{2}$, spike length, number of grains/spike, grain yield/feddan, straw yield/feddan, harvest index as compared with all other treatments in both seasons.
\end{abstract}

Keywords: Belcocel; North Sinai; Wheat.

\section{INTRODUCTION}

Wheat (Triticum aestivum, L.) is considered as one of the important cereal crops in Egypt and all over the world used in human food and animal feed. Nowadays, increasing wheat production is the first important step of the Egyptian strategic aims to bridge the gap between wheat production and consumption. Such increase is likely to be achieved by increasing wheat cultivated areas and growing high yielding varieties combined by optimizing various agricultural practices. The intensive competition between wheat and berseem during the winter season ceils the possibility of more extension in wheat cultivated area in the old land. Sandy soil predominate is most newly cultivated. These soils suffer from a very low soil fertility level and very low water holding as well as nutrients retention capacities.

Seeding rate play an important role in the placement of seed at proper depth and stand establishment of the growing crop which ultimately affected crop growth and productivity. Mosanaei et al. (2017), Julio et al .(2017) and Masuma et al .2017) found that increased plant density significantly increased plant height, spike length, number of seeds per spike, number of spikelet per spike, weight of 1000 seed, grain yield, straw yield, biological yield and harvest index .

Growth regulators were always a matter for solving many agricultural problems related to inferior growth, plant lodging and less in productivity due to environment factors including air, water and soil. Belcocel or Chloromequat chloride is a synthetic growth regulator, which increases resistance to lodging (by shortening and strengthening stems), and to increase yields in wheat (Eivazi, 2012; Latifkar and Mojaddm 2014). Berkesia et al. (2018) showed that application of Chloromequat chloride significantly increased number of spikes per square meter, 1000 grain weight, number of grains per spike, straw yield and grain yield as compared to control treatment.

Nitrogen is the most important plant nutrition needed obtained high wheat grain yield. Amin et al. (2011), Armin and Miri (2011), Haile et al. (2012), Fateh and Abdel-Dayem (2013), Swelem et al. (2015) and Ayadi et al. (2016) revealed that grain yield/fed, biological yield, harvest index, tiller number, ear length, number of spikes $/ \mathrm{m}^{2}$, number of grains/spike, 1000 grain weight, kernels weigh/spike and straw yield increased with increasing nitrogen fertilizer rate up to 120 $\mathrm{kg} \mathrm{N} /$ feddan.

The objective of this study was to evaluate the effect of seeding rates, belcocel rates as plant growth regulator, nitrogen fertilizer rates and their interactions on growth, yield and yield components of wheat Sakha 94 cultivar grown under reclaimed land conditions at El-Qantara East, North Sinai.

\section{MATERIALS AND METHODS}

Two field experiments were conducted at the experimental farm Agriculture Research Station, Desert Research Center, at El-Qantara East, North Sinai Governorate, Egypt, during 
$2015 / 2016$ and $2016 / 2017$ seasons, to investigate the effect of three seeding rates, three belcocel rates and four nitrogen fertilizer rates on yield and yield components of wheat cultivar Sakha 94.

\section{Seeding rates}

Three seeding rates were used i.e. 400, 500 and 600 seeds $/ \mathrm{m}^{2}$.

\section{Belcocel rates}

Three belcocel (Chloromequat chloride) rates were used, viz spraying wheat plants with tap water (control), spraying with belcocel at the rate of $750 \mathrm{~cm} 3 /$ fed once at 31 days from sowing and the rate of $375 \mathrm{~cm}^{3} /$ fed twice at 21 and 40 days from sowing. The spraying volume was $200 \mathrm{~L}$ water / feddan.

\section{Nitrogen fertilizer rates}

Four nitrogen fertilizer rates were applied i.e. control (without added nitrogen), 70, 90 and 110 $\mathrm{kg} \mathrm{N} /$ fed. Nitrogen fertilizer in the form of ammonium nitrate $(33.5 \% \mathrm{~N})$ of the previously studied rates was added in five equal splits at 15 days after sowing as basal dose, while the remainders were applied 10 days intervals.

A split split plot design with three replications was used whereas seeding rates were arranged in main plots and belcocel rates were devoted in sub plots as well as nitrogen fertilizer rates were allocated randomly in the Sub sub plots. The experimental unit was $10.5 \mathrm{~m}^{2}$ (15 rows x $0.2 \mathrm{~m}$ apart x $3.5 \mathrm{~m}$ long). Wheat seeds of Sakha 94 variety were sown on 22 and 16 November in the first and second seasons, respectively.

Mechanical and chemical analyses of soil at the experimental site in 2015/2016 and 2016/2017 seasons according to Jackson (1973) are shown in Table (1). Chemical properties of the irrigation water during the two growing seasons are illustrated in Table (2). Irrigation was done using modern irrigation (Sprinkler irrigation).

Recommended $\mathrm{P}$ and $\mathrm{K}$ fertilizers were added fully during soil preparation at the rate of 200 $\mathrm{kg} /$ fed calcium super phosphate (15.5\% P2 O5) and $50 \mathrm{~kg} / \mathrm{fed}$ potassium sulphate (48\% K2O). Weeds were mechanically controlled. All other normal agronomic recommended practices of wheat growing were done.

Table 1. Mechanical and chemical soil analyses at the experimental site in 2015/2016 and 2016/2017 seasons.

\begin{tabular}{|c|c|c|}
\hline Item & \multicolumn{2}{|c|}{ Season } \\
\hline Soil analyses & $2015 / 16$ & $2016 / 17$ \\
\hline \multicolumn{3}{|l|}{ Mechanical analysis } \\
\hline Sand (\%) & 87.40 & 86.02 \\
\hline Silt (\%) & 9.20 & 9.65 \\
\hline Clay (\%) & 3.40 & 4.23 \\
\hline Soil texture class & Sandy & Sandy \\
\hline \multicolumn{3}{|l|}{ Chemical analysis } \\
\hline $\mathrm{CaCo} 3$ & 0.37 & 0.33 \\
\hline $\mathrm{pH}$ & 7.95 & 7.86 \\
\hline E.C. $\left(\mathrm{dS} . \mathrm{m}^{-1}\right)$ & 0.72 & 0.70 \\
\hline Organic matter (\%) & 0.54 & 0.68 \\
\hline $\mathrm{Na}^{+}$ & 3.85 & 3.74 \\
\hline $\mathrm{K}^{+}$ & 0.36 & 0.35 \\
\hline $\mathrm{Ca}^{++}$ & 1.66 & 1.58 \\
\hline $\mathrm{Mg}^{++}$ & 1.33 & 1.31 \\
\hline $\mathrm{HCO}_{3}-$ & 1.99 & 1.97 \\
\hline $\mathrm{Cl}^{-}$ & 3.32 & 3.30 \\
\hline $\mathrm{SO} 4-$ & 1.89 & 1.87 \\
\hline SAR & 3.15 & 3.14 \\
\hline ESP & 3.27 & 3.26 \\
\hline
\end{tabular}

Table 2. The irrigation water analyses at the experimental site in both seasons.

\begin{tabular}{|c|c|c|c|c|}
\hline $\begin{array}{l}\text { Water analyses } \\
\text { E.C }{ }_{w}(p p m) \\
\text { pH }\end{array}$ & & & $\begin{array}{c}2015 / 2016 \text { Season } \\
2960 \\
8.3 \\
\end{array}$ & $\begin{array}{c}2016 / 2017 \text { Season } \\
2974 \\
8.6 \\
\end{array}$ \\
\hline \multirow{2}{*}{$\begin{array}{l}\text { Soluble ions } \\
\left(\mathrm{Meq} \mathrm{L}^{-1}\right)\end{array}$} & Cation & $\begin{array}{l}\mathrm{Ca}^{++} \\
\mathrm{Mg}^{++} \\
\mathrm{Na}^{+} \\
\mathrm{K}^{++}\end{array}$ & $\begin{array}{c}6.71 \\
8.39 \\
14.35 \\
0.28\end{array}$ & $\begin{array}{c}6.86 \\
8.43 \\
14.47 \\
0.29\end{array}$ \\
\hline & Anion & $\begin{array}{l}\mathrm{CO}^{-} \\
\mathrm{HCO}_{3-}^{-} \\
\mathrm{Cl}^{-} \\
\mathrm{SO}^{--}\end{array}$ & $\begin{array}{c}0.3 \\
2.9 \\
22.2 \\
3.1\end{array}$ & $\begin{array}{c}0.4 \\
2.9 \\
22.4 \\
3.6\end{array}$ \\
\hline
\end{tabular}




\section{Data recorded}

\section{A- Yield and yield components}

At harvest time at $15^{\text {th }}$ and $12^{\text {th }}$ April in the first and the second seasons, respectively, the inner eleven rows were harvested to determine the following data.

1-Number of spiked $/ \mathrm{m}^{2}$. It was calculated by counting all spikes per square meter.

2 - Spike length (cm): It was calculated of ten main spikes which randomly chosen.

3-Number of grains/Spike: average number of grains per ten randomly chosen spikes.

4-1000 grain weight (g): random samples of 1000 grain were taken from each plot hand counted and weighted.

5-Grain yield (ardab /fed): It was determined from the whole grain yield of each sub sub plot in terms of $\mathrm{kg} /$ plot and converted to ardab (ardab $=150 \mathrm{~kg}$ ) per feddan.

6-Straw yield (ton/fed): It was determined from the whole plants of each sub-sub plots in terms of $\mathrm{kg} / \mathrm{plot}$ and converted to tons of straw per feddan.

7-Harvest index (HI\%): It was determined according to the following formula:

Harvest index $(\mathrm{HI} \%)=($ Grain yield/Biological yield $)$ $\times 100$.

\section{Statistical analysis}

Data collected in the two seasons were statistically analyzed according to Snedecor and Cochan (1982). Comparison difference between means of treatments was tested for significance against L.S.D value at 5\% level of probability.

\section{RESULTS AND DISCUSSION}

Averages of number of spikes $/ \mathrm{m}^{2}$, spike length, 1000 grains weight, number of grain/spike, grain yield/feddan, straw yield/feddan, harvest index, as affected by seeding rates, belcocel as well as nitrogen fertilizer rates and their interactions in 2015/2016 and 2016/ 2017 seasons were shown in Tables 3 9)

Results presented in Tables (3-9) show clearly that the effect of seeding rates was significant on number of spikes $/ \mathrm{m}^{2}$, spike length, number of grain/spike, grain yield/feddan and straw yield/feddan in both seasons, while harvest index was significantly affected in the second season. On the other hand, 1000 grains weight was insignificant affected in both seasons. Sowing wheat plants at seeding rate of 600 seeds $/ \mathrm{m}^{2}$ gave the highest number of spikes $/ \mathrm{m}^{2} 672.00$ and 717.06, spike length 7.25 and $9.17 \mathrm{~cm}$, number of grains/spike 32.42 and 42.64, grain yield 10.59 and 12.45 arddab/feddan and straw yield 2.21 and 2.77 tons/feddan as compared with other seeding rates in 2015/2016 and 2016/2017 seasons, respectively. While, this seeding rate $(600$ seeds $/ \mathrm{m}^{2}$ ) gave the highest harvest index $40.05 \%$ in the second season.

The increase in grain yield per feddan owing to the highest seeding rate may be attributed to it gave the highest values of number of spike $/ \mathrm{m}^{2}$ (Table 3), spike length (Table 4) and number of grain/spike (Table 5) which led to raising grain yield per feddan. These results are in harmony with those of Mosanaei et al. (2017), Julio et al. (2017) and Masuma et al. (2017).

Result recorded in Tables 3-9 indicate that the effect of belcocel rates was significant on all studied traits in both seasons. Wheat plants sprayed twice with belcocel at the rate of 375 $\mathrm{cm}^{3} /$ feddan twice at 21 and 40 days from sowing date gave the highest values of grain yield/feddan 10.73 and 12.44 arddab as well as straw yield 2.21 and 2.76 tons as compared with all other treatise in 2015/2016 and 2016/2017 season, respectively.

The increase in grain yield per feddan due to spraying wheat plants with belcocel twice at the rate of $375 \mathrm{~cm}^{3} /$ feddan may be attributed to that it gave the highest values of yield components i.e number of spike/ $\mathrm{m}^{2}$, spike length, and number of grains/spike (Tables 3, 4 and 5). These results are in agreement with those of Latifkar and Mojaddam (2014) and Berkesia et al. (2018).

Results tabulated in Tables 3 -9 illustrate that all studied traits significantly affected by nitrogen fertilizer rates in both seasons. Application nitrogen fertilizer at the rate of $90 \mathrm{~kg}$ $\mathrm{N} /$ feddan surpassed other rates in all studied characters of wheat in both seasons. Increasing nitrogen fertilizer from $0 \mathrm{~kg} \mathrm{~N} /$ feddan (without $\mathrm{N}$ added) to $90 \mathrm{~kg} \mathrm{~N} /$ feddan increased number of spike $/ \mathrm{m}^{2}$ by 12.07 and $32.19 \%$, spike length by $52-51$ and $20.69 \%$, number of grains /spike by 41.24 and $29.64 \%, 1000$ grain weight by 14.42 and $13.19 \%$ grain yield/feddan by 75.94 and $49.55 \%$, strew yield/feddan by 18.95 and $14.69 \%$ harvest index by 27.03 and $17.87 \%$, in 2015/2016 and 2016/2017 seasons, respectively.

The increase in grain yield per feddan due to increasing nitrogen fertilizer rate might be attributed to nitrogen caused increases of plant growth and net assimilation rate which led to raising yield components (number of spike $/ \mathrm{m}^{2}$, spike length, and number of grains/spike) thus increased grain yield per feddan. These results are in the same line with those obtained by Haile et al. (2012), Fateh and Abdel-Dayem (2013), Swelem et al. (2015) and Ayadi et al. (2016).

The obtained results showed clearly that the interaction effect between seeding rates and belcocel rates was significant on all studied traits in both seasons, except spike length, number of grains/spike and 1000 grain weight were insignificantly affected in 2016/2017 season. 
Sowing wheat plants at seeding rate of 600 seeds $/ \mathrm{m}^{2}$ and sprayed with belcocel at the rate of $375 \mathrm{~cm}^{3} /$ feddan twice gave the highest number of spikes/m² 726.00 and 763.00 , grain yield/feddan 11.00 and 12.83 arddab and straw yield/feddan 2.28 and 2.84 tons as compared with all other treatments in 2015/2016 and 2016/2017 seasons, respectively.

Results in Tables 3- 9 indicate that sowing wheat plants at seeding rate of 600 seeds $/ \mathrm{m}^{2}$ and fertilized by nitrogen fertilizer at the rate of $90 \mathrm{~kg}$ $\mathrm{N} /$ feddan gave the highest values of number of spikes $/ \mathrm{m}^{2} 706.67$ and 780.67 , spike length 8.00 and $10.06 \mathrm{~cm}$, grain yield/feddan 11.95 and 13.74 arddab and straw yield/feddan 2.35 and 2.90 tons as compared with all other treatments in both seasons, respectively.

The obtained results showed clearly that spraying wheat plants twice by belcocel at the rate of $375 \mathrm{~cm}^{3} / \mathrm{fed}$ and fertilized with nitrogen at a rate of $90 \mathrm{~kg} \mathrm{~N} /$ fed gave the highest number of spikes $/ \mathrm{m}^{2} 651.11$ and 772.11 , spike length 8.54 and 10.40, number of grains/spike 37.07 and 47.66, grain yield/fed 12.21 and 13.66 arddab and straw yield/fed 2.35 and 2.90 tons as compared to all treatments in both seasons, respectively.

Results recorded in Tables 3-9 indicate that sowing wheat plants with seeding rate of 600 seeds $/ \mathrm{m}^{2}$, sprayed by belcocel twice at the rate of $375 \mathrm{~cm}^{3} /$ feddan twice and fertilized by nitrogen at the rate of $90 \mathrm{~kg} \mathrm{~N} /$ feddan gave the highest values of number of spikes $/ \mathrm{m}^{2} 780.00$ and 835.00 , grain yield/feddan 12.38 and 14.06 arddab and straw yield/feddan 2.34 and 2.98 tons as compared with all other treatments in 2015/2016 and 2016/2017seasons, respectively.

Generally, it could be recommended that sowing wheat variety Sakha 94 at seeding rate of 600 seeds $/ \mathrm{m}^{2}$ and sprayed by belcocel at the rate of $375 \mathrm{~cm}^{3} /$ feddan twice at 21 and 40 days from sowing as well as fertilized by nitrogen at the rate of $90 \mathrm{~kg} \mathrm{~N} /$ feddan increased grain and straw yield under North Sinai conditions.

\section{REFERENCES}

Amin, G.A.M., Geweifel H.G., Gomaa, M.A., El-Kholy, M.A., Mohamed, M.H., 2011. Effect of sowing methods and fertilization on yield analysis and grain quality of wheat under new reclaimed sandy soil. J. Appl. Sci. Res. December, $1760-1767$

Armin, M.G. Miri, H., 2011. Effect of plant density and nitrogen rate on yield and yield components of wheat in wild oat-infested condition. Adv. Environ. Biol. 5 (10), 3084-3090.

Ayadi, S., Karmous, C., Chamekh, Z., Hammami, Z., Baraket, M., Esposito, S. Rezgui, S., 2016 Effect of nitrogen rates on grain yield and nitrogen agronomic efficiency of durum wheat genotypes under different environments. Ann. Appl. Biol. 168 (2), 264-273.

Eivazi, A., 2012. Induction of drought tolerance with seed priming in wheat cultivars (Triticum aestivum L.). Acta Agric. Slov. 99 (1), 21-29.

Berkesia, S.N., Singh, B., Kainwal, M.K., 2018. Potential productivity and economics of feed barley as influenced by different nitrogen levels and plant growth regulators. Int. J. Agric. Sci. 10, 6150-6152.

Fateh, H.S.A., Abdel-Dayem, S.M., 2013. Nitrogen fertilizer use efficiency in some wheat cultivars. Bull. Fac. Agric. Cairo Univ. 64 (2), 140-151.

Haile, D., Nigussie, D., Ayana., A. 2012. Nitrogen use efficiency of bread wheat: Effect of nitrogen rate and time of application. J. Soil Sci. Plant Nutr. 12 (3), 389409.

Jackson, M.L., 1973. Soil Chemical Analysis Prentice Hall of Indian, Private, New Delhi.

Julio, I.S., Ben P., Asheesh, K.S., Wang, H., Ronald, M.D., Curtis, J.P., Brian, L.B., Eric, N.J., Richard, D.C., 2017. Effects of seeding rate on durum crop production and physiological responses. Agron. J. 109 (5),1981-1990.

Latifkar, M., Mojaddm, M., 2014. The effect of application time of cycocel hormone and plant density on growth indices and grain yield of wheat (Chamraan cultivar) in Ahvaz weather conditions. Ind. J. Fundam. Appl. Sci. 4 (4), 274-283.

Masuma, A., EL Sabaghb, A., Alam, M.N., Hasan, M.K., Hafezb, E., Barutçular C., Islam, S., 2017. Determination of seed rate of wheat (Triticum aestivum $\mathrm{L}$.) varieties with varying seed size. Scientific J. Crop Sci. 6 (3), 161-167.

Mosanaei, H., Ajamnorozi, H., Mohammad, R.D., Dadashi, M.R., Faraji, A., Pessakli, M., 2017. Improvement effect of nitrogen fertilizer and plant density of wheat (Triticum aestivum L.) seed deterioration and yield Emir. J. Food Agric. 29 (11), 899-910.

Snedecor, G.W., Cochran, W.G., 1982. Statistical. Methods $7^{\text {th }}$ Editon. The Iowa State Press, Ainess, Iowa.

Swelem, A.A., Hassan, M.A., Osman, E.A.M., 2015. Effect of raised bed width and nitrogen fertilizer level on productivity and nutritional status of bread wheat. Egypt. J. Appl. Sci. 30 (3), 223-234. 
Table 3. Average number of spike/ $\mathrm{m}^{2}$ of wheat as influenced by seeding rates, belcocel and nitrogen fertilizer rates as well as their interactions in 2015/2016 and 2016/2017 seasons.

\begin{tabular}{|c|c|c|c|c|c|c|c|c|c|c|c|}
\hline \multirow{3}{*}{ seeding rate } & \multirow{3}{*}{$\frac{\text { Belcocel }}{\text { rate }\left(\mathrm{cm}^{3} / \mathrm{fed}\right)}$} & \multirow{2}{*}{\multicolumn{4}{|c|}{$\begin{array}{c}\text { 2015/2016 season } \\
\text { Nitrogen rate } \\
\end{array}$}} & \multirow{3}{*}{ Mean } & \multirow{2}{*}{\multicolumn{4}{|c|}{$\begin{array}{c}\text { 2016/2017 season } \\
\text { Nitrogen rate }\end{array}$}} & \multirow{3}{*}{ Mean } \\
\hline & & & & & & & & & & & \\
\hline & & $0 \mathrm{~kg} \mathrm{~N} / \mathrm{fed}$ & $\begin{array}{l}70 \mathrm{~kg} \\
\mathrm{~N} / \mathrm{fed} \\
\end{array}$ & $\begin{array}{l}90 \mathrm{~kg} \\
\mathrm{~N} / \text { fed }\end{array}$ & $\begin{array}{l}110 \mathrm{~kg} \\
\mathrm{~N} / \mathrm{fed}\end{array}$ & & $\begin{array}{c}0 \mathrm{~kg} \\
\mathrm{~N} / \mathrm{fed} \\
\end{array}$ & $\begin{array}{l}70 \mathrm{~kg} \\
\mathrm{~N} / \text { fed }\end{array}$ & $\begin{array}{l}90 \mathrm{~kg} \\
\mathrm{~N} / \mathrm{fed}\end{array}$ & $\begin{array}{l}110 \mathrm{~kg} \\
\mathrm{~N} / \mathrm{fed}\end{array}$ & \\
\hline \multirow{3}{*}{400 grain $/ \mathrm{m}^{2}$} & Water & 400.33 & 413.33 & 440.00 & 426.67 & 420.08 & 400.00 & 590.67 & 640.00 & 600.00 & 557.67 \\
\hline & 750 once & 454.33 & 480.00 & 493.33 & 470.00 & 474.42 & 466.67 & 626.00 & 693.00 & 625.33 & 602.75 \\
\hline & 375 twice & 480.00 & 493.33 & 506.67 & 493.33 & 493.33 & 493.33 & 666.67 & 733.33 & 640.00 & 633.33 \\
\hline \multicolumn{2}{|c|}{ Mean } & 444.89 & 462.22 & 480.00 & 463.33 & 462.61 & 453.33 & 627.78 & 688.78 & 621.78 & 597.92 \\
\hline \multirow{3}{*}{500 grain $/ \mathrm{m}^{2}$} & Water & 500.00 & 545.67 & 550.00 & 533.33 & 532.25 & 526.67 & 532.67 & 626.33 & 547.67 & 558.33 \\
\hline & 750 once & 533.33 & 583.33 & 600.33 & 550.00 & 566.75 & 547.67 & 667.00 & 686.67 & 584.67 & 621.50 \\
\hline & 375 twice & 550.00 & 633.00 & 666.67 & 583.33 & 608.25 & 586.67 & 714.67 & 748.00 & 626.00 & 668.83 \\
\hline \multicolumn{2}{|c|}{ Mean } & 527.78 & 587.33 & 605.67 & 555.56 & 569.08 & 553.67 & 638.11 & 687.00 & 586.11 & 616.22 \\
\hline \multirow{3}{*}{600 grain / $\mathrm{m}^{2}$} & Water & 600.00 & 620.00 & 640.00 & 620.00 & 620.00 & 593.00 & 667.00 & 715.00 & 698.33 & 668.33 \\
\hline & 750 once & 620.00 & 680.00 & 700.00 & 680.00 & 670.00 & 620.00 & 730.67 & 792.00 & 736.67 & 719.83 \\
\hline & 375 twice & 660.00 & 764.00 & 780.00 & 700.00 & 726.00 & 660.00 & 762.00 & 835.00 & 795.00 & 763.00 \\
\hline \multicolumn{2}{|c|}{ Mean } & 626.67 & 688.00 & 706.67 & 666.67 & 672.00 & 624.33 & 719.89 & 780.67 & 743.33 & 717.06 \\
\hline \multirow{3}{*}{ G- mean of B } & Water & 500.11 & 526.33 & 543.33 & 526.67 & 524.11 & 506.56 & 596.78 & 660.44 & 615.33 & 594.78 \\
\hline & 750 once & 535.89 & 581.11 & 597.89 & 566.67 & 570.39 & 544.78 & 674.56 & 723.89 & 648.89 & 648.03 \\
\hline & 375 twice & 563.33 & 630.11 & 651.11 & 592.22 & 609.19 & 580.00 & 714.44 & 772.11 & 687.00 & 688.39 \\
\hline \multicolumn{2}{|c|}{ G- mean of $N$} & 533.11 & 579.19 & 597.44 & 561.85 & & 543.78 & 661.93 & 718.81 & 650.41 & \\
\hline
\end{tabular}

L.S.D at $5 \%$ level for:

$\begin{array}{ll}\text { Seeding rate } & \text { (S) } \\ \text { Belcocel } & \text { (B) } \\ \text { Nitrogen } & (\mathrm{N}) \\ \mathrm{S} \times \mathrm{B} & \\ \mathrm{S} \times \mathrm{N} & \\ \mathrm{B} \times \mathrm{N} & \\ \mathrm{S} \times \mathrm{B} \times \mathrm{N} & \end{array}$

$\begin{array}{ll}8.62 & 10.42 \\ 4.23 & 7.01 \\ 5.15 & 8.10 \\ 7.33 & 12.14 \\ 8.93 & 14.03 \\ 8.93 & 14.03 \\ 15.46 & 24.30\end{array}$


Table 4. Average spike length $(\mathrm{cm})$ of wheat as influenced by seeding rates, belcocel and nitrogen fertilizer rates as well as their interactions in $2015 / 2016$ and 2016/2017 seasons.

\begin{tabular}{|c|c|c|c|c|c|c|c|c|c|c|c|}
\hline \multirow{4}{*}{ seeding rate } & \multirow{3}{*}{$\frac{\text { Belcocel }}{\text { rate }\left(\mathrm{cm}^{3} / \mathrm{fed}\right)}$} & \multicolumn{4}{|c|}{ 2015/2016 season } & \multirow{3}{*}{ Mean } & \multirow{2}{*}{\multicolumn{4}{|c|}{$\frac{2016 / 2017 \text { season }}{\text { Nitrogen rate }}$}} & \multirow{3}{*}{ Mean } \\
\hline & & \multicolumn{4}{|c|}{ Nitrogen rate } & & & & & & \\
\hline & & $0 \mathrm{~kg} \mathrm{~N} / \mathrm{fed}$ & $\begin{array}{l}70 \mathrm{~kg} \\
\mathrm{~N} / \text { fed }\end{array}$ & $\begin{array}{l}90 \mathrm{~kg} \\
\mathrm{~N} / \mathrm{fed}\end{array}$ & $\begin{array}{l}110 \mathrm{~kg} \\
\mathrm{~N} / \mathrm{fed}\end{array}$ & & $\begin{array}{c}0 \mathrm{~kg} \\
\mathrm{~N} / \mathrm{fed}\end{array}$ & $\begin{array}{l}70 \mathrm{~kg} \\
\mathrm{~N} / \text { fed }\end{array}$ & $\begin{array}{l}90 \mathrm{~kg} \\
\mathrm{~N} / \text { fed }\end{array}$ & $\begin{array}{l}110 \mathrm{~kg} \\
\mathrm{~N} / \mathrm{fed}\end{array}$ & \\
\hline & 375 twice & 6.08 & 7.33 & 8.70 & 8.09 & 7.55 & 8.73 & 9.41 & 10.17 & 9.37 & 9.42 \\
\hline \multicolumn{2}{|c|}{ Mean } & 5.14 & 6.93 & 7.70 & 7.23 & 6.75 & 7.94 & 8.86 & 9.51 & 9.04 & 8.84 \\
\hline \multirow{3}{*}{500 grain $/ \mathrm{m}^{2}$} & Water & 4.19 & 6.87 & 7.28 & 7.04 & 6.34 & 7.14 & 8.48 & 9.33 & 8.40 & 8.34 \\
\hline & 750 once & 5.04 & 7.46 & 7.95 & 7.53 & 7.00 & 8.50 & 9.41 & 10.13 & 8.89 & 9.23 \\
\hline & 375 twice & 6.35 & 8.61 & 8.75 & 7.47 & 7.80 & 9.20 & 9.71 & 10.53 & 9.30 & 9.69 \\
\hline \multicolumn{2}{|c|}{ Mean } & 5.19 & 7.65 & 7.99 & 7.35 & 7.05 & 8.28 & 9.20 & 10.00 & 8.86 & 9.09 \\
\hline \multirow{3}{*}{600 grain $/ \mathrm{m}^{2}$} & Water & 4.60 & 7.78 & 7.89 & 7.87 & 7.04 & 7.13 & 8.67 & 9.25 & 9.03 & 8.52 \\
\hline & 750 once & 5.01 & 7.85 & 7.94 & 7.88 & 7.17 & 8.45 & 9.60 & 10.43 & 9.22 & 9.43 \\
\hline & 375 twice & 6.00 & 7.99 & 8.16 & 8.00 & 7.54 & 9.30 & 9.90 & 10.50 & 8.53 & 9.56 \\
\hline \multicolumn{2}{|c|}{ Mean } & 5.20 & 7.87 & 8.00 & 7.92 & 7.25 & 8.29 & 9.39 & 10.06 & 8.93 & 9.17 \\
\hline \multirow{3}{*}{ G- mean of B } & Water & 4.32 & 6.96 & 7.31 & 7.04 & 6.41 & 7.13 & 8.45 & 9.15 & 8.64 & 8.34 \\
\hline & 750 once & 5.08 & 7.52 & 7.84 & 7.61 & 7.01 & 8.30 & 9.33 & 10.02 & 9.12 & 9.19 \\
\hline & 375 twice & 6.14 & 7.98 & 8.54 & 7.85 & 7.63 & 9.08 & 9.67 & 10.40 & 9.07 & 9.56 \\
\hline \multicolumn{2}{|c|}{ G- mean of $N$} & 5.18 & 7.48 & 7.90 & 7.50 & & 8.17 & 9.15 & 9.86 & 8.94 & \\
\hline
\end{tabular}

L.S.D at $5 \%$ level for:

$\begin{array}{lll}\text { Seeding rate } & \text { (S) } & 0.15 \\ \text { Belcocel } & \text { (B) } & 0.14 \\ \text { Nitrogen } & \text { (N) } & 0.13 \\ \mathrm{~S} \times \mathrm{B} & & 0.24 \\ \mathrm{~S} \times \mathrm{N} & & 0.22 \\ \mathrm{~B} \times \mathrm{N} & & 0.22 \\ \mathrm{~S} \times \mathrm{B} \times \mathrm{N} & & 0.39\end{array}$

0.21

0.07

0.01

NS

0.24

0.24

0.42 
Table 5. Average number of grains/spike of wheat as influenced by seeding rates, belcocel and nitrogen fertilizer rates as well as their interactions in 2015/2016 and 2016/2017 season.

\begin{tabular}{|c|c|c|c|c|c|c|c|c|c|c|c|}
\hline \multirow{3}{*}{ seeding rate } & \multirow{3}{*}{$\frac{\text { Belcocel }}{\text { rate }\left(\mathrm{cm}^{3} / \mathrm{fed}\right)}$} & \multirow{2}{*}{\multicolumn{4}{|c|}{$\begin{array}{c}\text { 2015/2016 season } \\
\text { Nitrogen rate }\end{array}$}} & \multirow{3}{*}{ Mean } & \multirow{2}{*}{\multicolumn{4}{|c|}{$\begin{array}{c}\text { 2016/2017 season } \\
\text { Nitrogen rate }\end{array}$}} & \multirow{3}{*}{ Mean } \\
\hline & & & & & & & & & & & \\
\hline & & $0 \mathrm{~kg} \mathrm{~N} / \mathrm{fed}$ & $\begin{array}{l}70 \mathrm{~kg} \\
\mathrm{~N} / \mathrm{fed} \\
\end{array}$ & $\begin{array}{l}90 \mathrm{~kg} \\
\mathrm{~N} / \mathrm{fed} \\
\end{array}$ & $\begin{array}{l}110 \mathrm{~kg} \\
\mathrm{~N} / \mathrm{fed}\end{array}$ & & $\begin{array}{c}0 \mathrm{~kg} \\
\mathrm{~N} / \mathrm{fed} \\
\end{array}$ & $\begin{array}{l}70 \mathrm{~kg} \\
\mathrm{~N} / \mathrm{fed}\end{array}$ & $\begin{array}{l}90 \mathrm{~kg} \\
\mathrm{~N} / \mathrm{fed}\end{array}$ & $\begin{array}{l}110 \mathrm{~kg} \\
\mathrm{~N} / \mathrm{fed} \\
\end{array}$ & \\
\hline \multirow{3}{*}{400 grain $/ \mathrm{m}^{2}$} & Water & 22.10 & 31.30 & 32.57 & 30.67 & 29.16 & 31.75 & 40.63 & 44.18 & 42.63 & 39.80 \\
\hline & 750 once & 26.50 & 33.36 & 33.70 & 32.70 & 31.57 & 36.00 & 42.87 & 45.37 & 44.33 & 42.14 \\
\hline & 375 twice & 29.22 & 35.63 & 36.48 & 35.43 & 34.19 & 38.85 & 43.87 & 46.50 & 45.03 & 43.56 \\
\hline \multicolumn{2}{|c|}{ Mean } & 25.94 & 33.43 & 34.25 & 32.93 & 31.64 & 35.53 & 42.46 & 45.35 & 44.00 & 41.84 \\
\hline \multirow{3}{*}{500 grain $/ \mathrm{m}^{2}$} & Water & 21.43 & 30.53 & 33.53 & 31.17 & 29.17 & 32.90 & 41.13 & 42.80 & 42.40 & 39.81 \\
\hline & 750 once & 24.20 & 34.00 & 34.74 & 33.83 & 31.69 & 35.82 & 44.73 & 46.83 & 43.70 & 42.77 \\
\hline & 375 twice & 27.00 & 36.47 & 38.47 & 35.07 & 34.25 & 37.60 & 47.33 & 48.53 & 44.97 & 44.61 \\
\hline \multicolumn{2}{|c|}{ Mean } & 24.21 & 33.67 & 35.58 & 33.36 & 31.70 & 35.44 & 44.40 & 46.06 & 43.69 & 42.40 \\
\hline \multirow{3}{*}{600 grain $/ \mathrm{m}^{2}$} & Water & 20.43 & 33.47 & 34.90 & 33.90 & 30.68 & 31.53 & 40.90 & 45.80 & 43.43 & 40.42 \\
\hline & 750 once & 25.73 & 34.90 & 35.87 & 35.40 & 32.98 & 36.77 & 45.00 & 46.57 & 44.10 & 43.11 \\
\hline & 375 twice & 27.47 & 34.97 & 36.25 & 35.70 & 33.60 & 38.57 & 46.53 & 47.93 & 44.53 & 44.39 \\
\hline \multirow{3}{*}{ G- mean of B } & Water & 21.32 & 31.77 & 33.67 & 31.91 & 29.67 & 32.06 & 40.89 & 44.26 & 42.82 & 40.01 \\
\hline & 750 once & 25.48 & 34.09 & 34.77 & 33.98 & 32.08 & 36.19 & 44.20 & 46.26 & 44.04 & 42.67 \\
\hline & 375 twice & 27.89 & 35.69 & 37.07 & 35.40 & 34.01 & 38.34 & 45.91 & 47.66 & 44.84 & 44.19 \\
\hline \multicolumn{2}{|c|}{ G- mean of $\mathrm{N}$} & 24.90 & 33.85 & 35.17 & 33.76 & & 35.53 & 43.67 & 46.06 & 43.90 & \\
\hline
\end{tabular}

L.S.D at $5 \%$ level for:

$\begin{array}{lll}\text { seeding rate } & \text { (S) } & 0.22 \\ \text { Belcocel } & \text { (B) } & 0.41 \\ \text { Nitrogen } & \text { (N) } & 0.45 \\ \mathrm{~S} \times \mathrm{B} & & 0.71 \\ \mathrm{~S} \times \mathrm{N} & & 0.78 \\ \mathrm{~B} \times \mathrm{N} & & 0.78 \\ \mathrm{~S} \times \mathrm{B} \times \mathrm{N} & & 1.35\end{array}$


Table 6. Average 1000 grain weight (g) of wheat as influenced by seeding rates, belcocel and nitrogen fertilizer rates as well as their interactions in $2015 / 2016$ and 2016/2017 seasons.

\begin{tabular}{|c|c|c|c|c|c|c|c|c|c|c|c|}
\hline \multirow{3}{*}{ seeding rate } & \multirow{3}{*}{$\begin{array}{c}\text { Belcocel } \\
\begin{array}{c}\text { rate }\left(\mathrm{cm}^{3} /\right. \\
\text { fed })\end{array}\end{array}$} & \multicolumn{4}{|c|}{ 2015/2016 season } & \multirow{3}{*}{ Mean } & \multirow{2}{*}{\multicolumn{4}{|c|}{$\begin{array}{c}\text { 2016/2017 season } \\
\text { Nitrogen rate }\end{array}$}} & \multirow{3}{*}{ Mean } \\
\hline & & \multicolumn{4}{|c|}{ Nitrogen rate } & & & & & & \\
\hline & & $0 \mathrm{~kg} \mathrm{~N} / \mathrm{fed}$ & $\begin{array}{l}70 \mathrm{~kg} \\
\mathrm{~N} / \mathrm{fed}\end{array}$ & $\begin{array}{l}90 \mathrm{~kg} \\
\mathrm{~N} / \mathrm{fed} \\
\end{array}$ & $\begin{array}{l}110 \mathrm{~kg} \\
\mathrm{~N} / \mathrm{fed}\end{array}$ & & $\begin{array}{c}0 \mathrm{~kg} \\
\mathrm{~N} / \mathrm{fed}\end{array}$ & $\begin{array}{l}70 \mathrm{~kg} \\
\mathrm{~N} / \mathrm{fed} \\
\end{array}$ & $\begin{array}{l}90 \mathrm{~kg} \\
\mathrm{~N} / \mathrm{fed}\end{array}$ & $\begin{array}{l}110 \mathrm{~kg} \\
\mathrm{~N} / \mathrm{fed}\end{array}$ & \\
\hline & Water & 28.00 & 30.33 & 32.00 & 30.67 & 30.25 & 34.00 & 37.00 & 39.00 & 37.33 & 36.83 \\
\hline 400 grain $/ \mathrm{m}^{2}$ & 750 once & 29.00 & 32.00 & 34.00 & 32.00 & 31.75 & 36.33 & 38.67 & 40.67 & 38.67 & 38.58 \\
\hline & 375 twice & 30.67 & 34.00 & 35.00 & 33.43 & 33.28 & 37.33 & 40.67 & 42.03 & 40.67 & 40.18 \\
\hline \multicolumn{2}{|c|}{ Mean } & 29.22 & 32.11 & 33.67 & 32.03 & 31.76 & 35.89 & 38.78 & 40.57 & 38.89 & 38.53 \\
\hline & Water & 26.33 & 29.67 & 31.00 & 30.00 & 29.25 & 33.90 & 36.33 & 38.17 & 36.80 & 36.30 \\
\hline \multirow[t]{2}{*}{500 grain $/ \mathrm{m}^{2}$} & 750 once & 30.67 & 33.00 & 34.67 & 32.00 & 32.58 & 36.33 & 37.67 & 40.67 & 38.67 & 38.33 \\
\hline & 375 twice & 31.00 & 34.00 & 35.00 & 33.00 & 33.25 & 37.00 & 40.00 & 42.00 & 40.00 & 39.75 \\
\hline \multicolumn{2}{|c|}{ Mean } & 29.33 & 32.22 & 33.56 & 31.67 & 31.69 & 35.74 & 38.00 & 40.28 & 38.49 & 38.13 \\
\hline & Water & 27.33 & 31.00 & 31.33 & 30.00 & 29.92 & 34.00 & 37.00 & 37.00 & 36.00 & 36.00 \\
\hline \multirow[t]{2}{*}{600 grain $/ \mathrm{m}^{2}$} & 750 once & 30.33 & 33.00 & 34.00 & 32.00 & 32.33 & 35.33 & 39.00 & 41.33 & 39.00 & 38.67 \\
\hline & 375 twice & 30.00 & 33.67 & 34.33 & 33.00 & 32.75 & 36.33 & 40.00 & 42.00 & 40.00 & 39.58 \\
\hline \multicolumn{2}{|c|}{ Mean } & 29.22 & 32.56 & 33.22 & 31.67 & 31.67 & 35.22 & 38.67 & 40.11 & 38.33 & 38.08 \\
\hline & Water & 27.22 & 30.33 & 31.44 & 30.22 & 29.81 & 33.97 & 36.78 & 38.06 & 36.71 & 36.38 \\
\hline \multirow[t]{2}{*}{ G- mean of $B$} & 750 once & 30.00 & 32.67 & 34.22 & 32.00 & 32.22 & 36.00 & 38.44 & 40.89 & 38.78 & 38.53 \\
\hline & 375 twice & 30.56 & 33.89 & 34.78 & 33.14 & 33.09 & 36.89 & 40.22 & 42.01 & 40.22 & 39.84 \\
\hline \multicolumn{2}{|c|}{ G- mean of $\mathrm{N}$} & 29.26 & 32.30 & 33.48 & 31.79 & & 35.62 & 38.48 & 40.32 & 38.57 & \\
\hline
\end{tabular}

L.S.D at $5 \%$ level for:

$\begin{array}{ll}\text { Seeding rate } & (\mathrm{S}) \\ \text { Belcocel } & (\mathrm{B}) \\ \text { Nitrogen } & (\mathrm{N}) \\ \mathrm{S} \times \mathrm{B} & \\ \mathrm{S} \times \mathrm{N} \\ \mathrm{B} \times \mathrm{N} \\ \mathrm{S} \times \mathrm{B} \times \mathrm{N}\end{array}$

NS

0.41

N) 
Table 7. Average grain yield per feddan / ardab of wheat as influenced by seeding rates, belcocel and nitrogen fertilizer ratesas well as their interactions in 2015/2016 and 2016/2017 seasons.

\begin{tabular}{|c|c|c|c|c|c|c|c|c|c|c|c|}
\hline \multirow{3}{*}{ seeding rate } & \multirow{3}{*}{$\frac{\text { Belcocel }}{\text { rate }\left(\mathrm{cm}^{3} / \text { fed }\right)}$} & \multirow{2}{*}{\multicolumn{4}{|c|}{$\begin{array}{c}\text { 2015/2016 season } \\
\text { Nitrogen rate } \\
\end{array}$}} & \multirow{3}{*}{ Mean } & \multirow{2}{*}{\multicolumn{4}{|c|}{$\begin{array}{c}\text { 2016/2017 season } \\
\text { Nitrogen rate }\end{array}$}} & \multirow{3}{*}{ Mean } \\
\hline & & & & & & & & & & & \\
\hline & & $0 \mathrm{~kg} \mathrm{~N} / \mathrm{fed}$ & $70 \mathrm{~kg} \mathrm{~N} / \mathrm{fed}$ & $\begin{array}{c}90 \mathrm{~kg} \\
\mathrm{~N} / \mathrm{fed}\end{array}$ & $\begin{array}{l}110 \mathrm{~kg} \\
\mathrm{~N} / \mathrm{fed}\end{array}$ & & $\begin{array}{c}0 \mathrm{~kg} \\
\mathrm{~N} / \mathrm{fed}\end{array}$ & $\begin{array}{l}70 \mathrm{~kg} \\
\mathrm{~N} / \mathrm{fed}\end{array}$ & $\begin{array}{l}90 \mathrm{~kg} \\
\mathrm{~N} / \mathrm{fed}\end{array}$ & $\begin{array}{l}110 \mathrm{~kg} \\
\mathrm{~N} / \mathrm{fed}\end{array}$ & \\
\hline & Water & 5.70 & 10.28 & 10.42 & 10.30 & 9.18 & 7.48 & 11.89 & 12.09 & 11.90 & 10.84 \\
\hline \multirow[t]{2}{*}{400 grain $/ \mathrm{m}^{2}$} & 750 once & 6.20 & 10.85 & 11.78 & 11.65 & 10.12 & 8.26 & 12.68 & 13.09 & 12.56 & 11.65 \\
\hline & 375 twice & 6.40 & 11.81 & 12.20 & 11.84 & 10.56 & 9.05 & 13.13 & 13.41 & 13.05 & 12.16 \\
\hline \multicolumn{2}{|c|}{ Mean } & 6.10 & 10.98 & 11.47 & 11.26 & 9.95 & 8.26 & 12.57 & 12.86 & 12.50 & 11.55 \\
\hline & Water & 6.34 & 10.94 & 11.21 & 11.00 & 9.87 & 8.61 & 12.62 & 12.95 & 12.52 & 11.67 \\
\hline \multirow[t]{2}{*}{500 grain $/ \mathrm{m}^{2}$} & 750 once & 6.65 & 11.51 & 11.73 & 11.39 & 10.32 & 9.15 & 12.98 & 13.23 & 12.79 & 12.04 \\
\hline & 375 twice & 7.00 & 11.79 & 12.05 & 11.72 & 10.64 & 9.36 & 13.24 & 13.52 & 13.22 & 12.33 \\
\hline \multicolumn{2}{|c|}{ Mean } & 6.66 & 11.41 & 11.67 & 11.37 & 10.28 & 9.04 & 12.95 & 13.23 & 12.84 & 12.01 \\
\hline & Water & 6.88 & 11.03 & 11.40 & 11.11 & 10.11 & 8.86 & 12.95 & 13.41 & 13.00 & 12.06 \\
\hline \multirow[t]{2}{*}{600 grain $/ \mathrm{m}^{2}$} & 750 once & 7.20 & 11.81 & 12.09 & 11.54 & 10.66 & 9.41 & 13.41 & 13.74 & 13.28 & 12.46 \\
\hline & 375 twice & 7.52 & 12.10 & 12.38 & 11.99 & 11.00 & 9.76 & 13.83 & 14.06 & 13.67 & 12.83 \\
\hline \multicolumn{2}{|c|}{ Mean } & 7.20 & 11.65 & 11.95 & 11.55 & 10.59 & 9.34 & 13.39 & 13.74 & 13.32 & 12.45 \\
\hline & Water & 6.31 & 10.75 & 11.01 & 10.80 & 9.72 & 8.32 & 12.49 & 12.82 & 12.48 & 11.52 \\
\hline \multirow[t]{2}{*}{ G- mean of B } & 750 once & 6.68 & 11.39 & 11.87 & 11.52 & 10.37 & 8.94 & 13.02 & 13.35 & 12.87 & 12.05 \\
\hline & 375 twice & 6.97 & 11.90 & 12.21 & 11.85 & 10.73 & 9.39 & 13.40 & 13.66 & 13.31 & 12.44 \\
\hline \multicolumn{2}{|c|}{ G- mean of N } & 6.65 & 11.35 & 11.70 & 11.39 & & 8.88 & 12.97 & 13.28 & 12.89 & \\
\hline
\end{tabular}

Ardab $=150 \mathrm{~kg}$

L.S.D at $5 \%$ level for:

$\begin{array}{ll}\text { Seeding rate } & (\mathrm{S}) \\ \text { Belcocel } & (\mathrm{B}) \\ \text { Nitrogen } & (\mathrm{N}) \\ \mathrm{S} \times \mathrm{B} & \\ \mathrm{S} \times \mathrm{N} \\ \mathrm{B} \times \mathrm{N} \\ \mathrm{S} \times \mathrm{B} \times \mathrm{N}\end{array}$


Table 8. Average straw yield ton/fed of wheat as influenced by seeding rates, belcocel and nitrogen fertilizer rates as well as their interactions in 2015/2016 and 2016/2017 seasons.

\begin{tabular}{|c|c|c|c|c|c|c|c|c|c|c|c|}
\hline \multirow{3}{*}{ seeding rate } & \multirow{3}{*}{$\frac{\text { Belcocel }}{\text { rate }\left(\mathrm{cm}^{3} / \mathrm{fed}\right)}$} & \multicolumn{4}{|c|}{ 2015/2016 season } & \multirow{3}{*}{ Mean } & \multirow{2}{*}{\multicolumn{4}{|c|}{$\begin{array}{c}\text { 2016/2017 season } \\
\text { Nitrogen rate } \\
\end{array}$}} & \multirow{3}{*}{ Mean } \\
\hline & & \multicolumn{4}{|c|}{ Nitrogen rate } & & & & & & \\
\hline & & $0 \mathrm{~kg} \mathrm{~N} / \mathrm{fed}$ & $70 \mathrm{~kg} \mathrm{~N} / \mathrm{fed}$ & $\begin{array}{l}90 \mathrm{~kg} \\
\mathrm{~N} / \text { fed } \\
\end{array}$ & $\begin{array}{l}110 \mathrm{~kg} \\
\mathrm{~N} / \mathrm{fed}\end{array}$ & & $\begin{array}{c}0 \mathrm{~kg} \\
\mathrm{~N} / \text { fed } \\
\end{array}$ & $\begin{array}{l}70 \mathrm{~kg} \\
\mathrm{~N} / \mathrm{fed} \\
\end{array}$ & $\begin{array}{l}90 \mathrm{~kg} \\
\mathrm{~N} / \mathrm{fed} \\
\end{array}$ & $\begin{array}{l}110 \mathrm{~kg} \\
\mathrm{~N} / \mathrm{fed}\end{array}$ & \\
\hline \multirow{3}{*}{400 grain $/ \mathrm{m}^{2}$} & Water & 1.83 & 2.04 & 2.08 & 2.06 & 2.01 & 2.38 & 2.59 & 2.63 & 2.61 & 2.56 \\
\hline & 750 once & 1.86 & 2.10 & 2.18 & 2.15 & 2.07 & 2.41 & 2.71 & 2.73 & 2.70 & 2.64 \\
\hline & 375 twice & 1.91 & 2.19 & 2.22 & 2.16 & 2.12 & 2.46 & 2.74 & 2.77 & 2.71 & 2.67 \\
\hline \multicolumn{2}{|c|}{ Mean } & 1.87 & 2.11 & 2.16 & 2.13 & 2.07 & 2.42 & 2.68 & 2.71 & 2.68 & 2.62 \\
\hline \multirow{3}{*}{500 grain $/ \mathrm{m}^{2}$} & Water & 1.86 & 2.08 & 2.15 & 2.12 & 2.05 & 2.41 & 2.63 & 2.70 & 2.67 & 2.60 \\
\hline & 750 once & 1.88 & 2.21 & 2.26 & 2.20 & 2.14 & 2.43 & 2.76 & 2.81 & 2.75 & 2.69 \\
\hline & 375 twice & 1.90 & 2.31 & 2.40 & 2.29 & 2.23 & 2.45 & 2.90 & 2.95 & 2.84 & 2.78 \\
\hline \multicolumn{2}{|c|}{ Mean } & 1.88 & 2.20 & 2.27 & 2.21 & 2.14 & 2.43 & 2.76 & 2.82 & 2.76 & 2.69 \\
\hline \multirow{3}{*}{600 grain $/ \mathrm{m}^{2}$} & Water & 1.91 & 2.17 & 2.25 & 2.18 & 2.13 & 2.46 & 2.76 & 2.80 & 2.73 & 2.69 \\
\hline & 750 once & 1.95 & 2.26 & 2.37 & 2.30 & 2.22 & 2.50 & 2.87 & 2.92 & 2.85 & 2.79 \\
\hline & 375 twice & 1.98 & 2.36 & 2.43 & 2.36 & 2.28 & 2.53 & 2.91 & 2.98 & 2.91 & 2.84 \\
\hline \multicolumn{2}{|c|}{ Mean } & 1.95 & 2.26 & 2.35 & 2.28 & 2.21 & 2.50 & 2.85 & 2.90 & 2.83 & 2.77 \\
\hline \multirow{3}{*}{ G- mean of B } & Water & 1.87 & 2.10 & 2.16 & 2.12 & 2.06 & 2.42 & 2.66 & 2.71 & 2.67 & 2.62 \\
\hline & 750 once & 1.90 & 2.19 & 2.27 & 2.22 & 2.14 & 2.45 & 2.78 & 2.82 & 2.77 & 2.70 \\
\hline & 375 twice & 1.93 & 2.29 & 2.35 & 2.27 & 2.21 & 2.48 & 2.85 & 2.90 & 2.82 & 2.76 \\
\hline \multicolumn{2}{|c|}{ G- mean of $\mathrm{N}$} & 1.90 & 2.19 & 2.26 & 2.20 & & 2.45 & 2.76 & 2.81 & 2.75 & \\
\hline
\end{tabular}

L.S.D at $5 \%$ level for:

Seeding rate
Belcocel
Nitrogen
$\mathrm{S} \times \mathrm{B}$
$\mathrm{S} \times \mathrm{N}$
$\mathrm{B} \times \mathrm{N}$
$\mathrm{S} \times \mathrm{B} \times \mathrm{N}$


Table 9. Average harvest index $\%$ of wheat as influenced by seeding rates, belcocel and , nitrogen fertilizer rates as well as their interactions in $2015 / 2016$ and 2016/2017 seasons.

\begin{tabular}{|c|c|c|c|c|c|c|c|c|c|c|c|}
\hline \multirow{3}{*}{ seeding rate } & \multirow{3}{*}{$\frac{\text { Belcocel }}{\text { rate }\left(\mathrm{cm}^{3} / \mathrm{fed}\right)}$} & \multirow{2}{*}{\multicolumn{4}{|c|}{$\begin{array}{c}\text { 2015/2016 season } \\
\text { Nitrogen rate }\end{array}$}} & \multirow{3}{*}{ Mean } & \multirow{2}{*}{\multicolumn{4}{|c|}{$\begin{array}{c}\text { 2016/2017 season } \\
\text { Nitrogen rate }\end{array}$}} & \multirow{3}{*}{ Mean } \\
\hline & & & & & & & & & & & \\
\hline & & $0 \mathrm{~kg} \mathrm{~N} / \mathrm{fed}$ & $\begin{array}{l}70 \mathrm{~kg} \\
\mathrm{~N} / \text { fed }\end{array}$ & $\begin{array}{l}90 \mathrm{~kg} \\
\mathrm{~N} / \mathrm{fed}\end{array}$ & $\begin{array}{l}110 \mathrm{~kg} \\
\mathrm{~N} / \mathrm{fed}\end{array}$ & & $\begin{array}{c}0 \mathrm{~kg} \\
\mathrm{~N} / \mathrm{fed}\end{array}$ & $70 \mathrm{~kg} \mathrm{~N} / \mathrm{fed}$ & $\begin{array}{l}90 \mathrm{~kg} \\
\mathrm{~N} / \mathrm{fed} \\
\end{array}$ & $\begin{array}{l}110 \mathrm{~kg} \\
\mathrm{~N} / \mathrm{fed}\end{array}$ & \\
\hline \multirow{3}{*}{400 grain $/ \mathrm{m}^{2}$} & Water & 31.78 & 43.00 & 42.89 & 42.85 & 40.13 & 32.00 & 40.75 & 40.80 & 40.61 & 38.54 \\
\hline & 750 once & 33.30 & 43.68 & 44.74 & 44.79 & 41.63 & 33.91 & 41.25 & 41.81 & 41.06 & 39.51 \\
\hline & 375 twice & 33.51 & 44.69 & 45.15 & 45.07 & 42.10 & 35.59 & 41.79 & 42.05 & 41.89 & 40.33 \\
\hline \multicolumn{2}{|c|}{ Mean } & 32.86 & 43.79 & 44.26 & 44.23 & 41.29 & 33.84 & 41.26 & 41.55 & 41.19 & 39.46 \\
\hline & Water & 33.82 & 44.04 & 43.90 & 43.71 & 41.37 & 34.89 & 41.81 & 41.85 & 41.25 & 39.95 \\
\hline \multirow[t]{2}{*}{500 grain $/ \mathrm{m}^{2}$} & 750 once & 34.69 & 43.86 & 43.83 & 43.66 & 41.51 & 36.10 & 41.37 & 41.43 & 41.05 & 39.99 \\
\hline & 375 twice & 35.64 & 43.33 & 43.00 & 43.37 & 41.33 & 36.46 & 40.67 & 40.77 & 41.07 & 39.74 \\
\hline \multicolumn{2}{|c|}{ Mean } & 34.72 & 43.74 & 43.58 & 43.58 & 41.40 & 35.82 & 41.28 & 41.35 & 41.12 & 39.89 \\
\hline & Water & 35.06 & 43.30 & 43.21 & 43.38 & 41.24 & 35.05 & 41.31 & 41.84 & 41.71 & 39.98 \\
\hline \multirow[t]{2}{*}{600 grain $/ \mathrm{m}^{2}$} & 750 once & 35.62 & 43.97 & 43.38 & 42.89 & 41.47 & 36.08 & 41.17 & 41.41 & 41.10 & 39.94 \\
\hline & 375 twice & 36.25 & 43.44 & 43.28 & 43.26 & 41.56 & 36.62 & 41.58 & 41.41 & 41.34 & 40.24 \\
\hline \multicolumn{2}{|c|}{ Mean } & 35.64 & 43.57 & 43.29 & 43.18 & 41.42 & 35.91 & 41.35 & 41.55 & 41.39 & 40.05 \\
\hline & Water & 33.55 & 43.45 & 43.33 & 43.31 & 40.91 & 33.98 & 41.29 & 41.50 & 41.19 & 39.49 \\
\hline \multirow[t]{2}{*}{ G- mean of B } & 750 once & 34.54 & 43.83 & 43.98 & 43.78 & 41.53 & 35.36 & 41.26 & 41.55 & 41.07 & 39.81 \\
\hline & 375 twice & 35.13 & 43.82 & 43.81 & 43.90 & 41.67 & 36.22 & 41.35 & 41.41 & 41.44 & 40.10 \\
\hline \multicolumn{2}{|c|}{ G- mean of $N$} & 34.41 & 43.70 & 43.71 & 43.66 & & 35.19 & 41.30 & 41.48 & 41.23 & \\
\hline
\end{tabular}

L.S.D at $5 \%$ level for:

$\begin{array}{ll}\text { Seeding rat } & (\mathrm{S}) \\ \text { Belcocel } & (\mathrm{B}) \\ \text { Nitrogen } & (\mathrm{N}) \\ \mathrm{S} \times \mathrm{B} & \\ \mathrm{S} \times \mathrm{N} \\ \mathrm{B} \times \mathrm{N} \\ \mathrm{S} \times \mathrm{B} \times \mathrm{N}\end{array}$

(S)

(B)

Ns

0.17

0.22

0.30

0.38

0.38

0.67
0.13

0.15

0.19

0.27

0.33

0.33

NS 


\title{
تاثير معدلات الثقاوي والبيلكوسيل والسهاد النيترجينى على المصول ومكوناته فى القمح تحت ظروف شال سيناء
}

\author{
محمد الاسمر الهواري '، جال الدين حسن عبد الحي '، محمد عبد الميد عطية '، محمد عبد المنعم ابراهيم زعير '

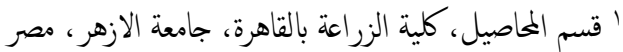

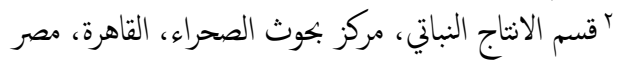

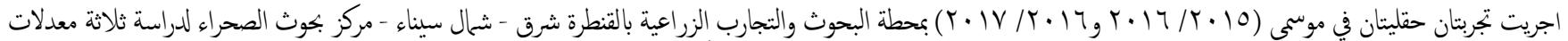

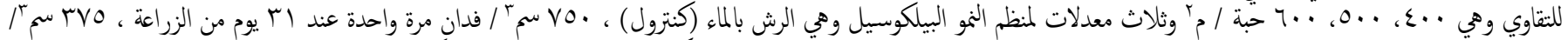

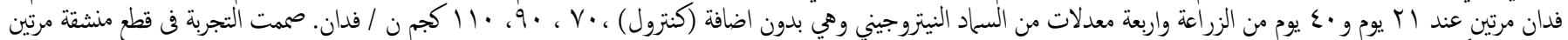

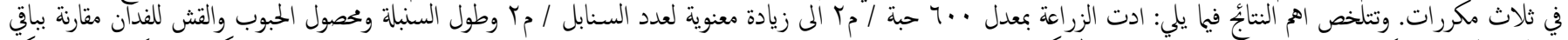

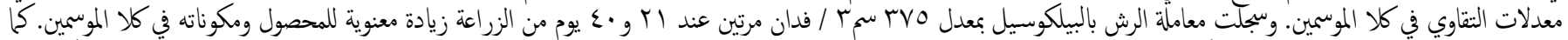

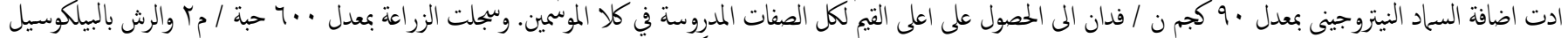

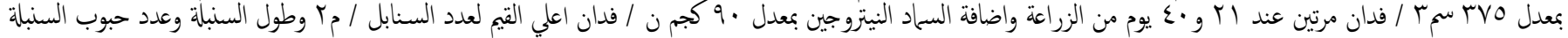

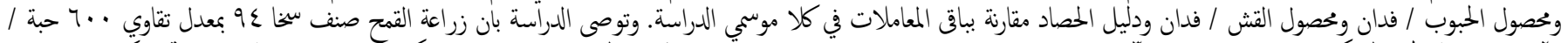

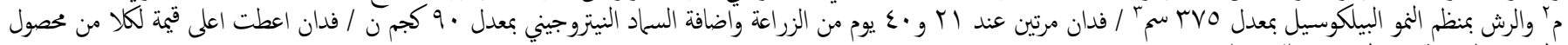
الخبوب والقش تحت ظروف شال سيناء. 